\title{
Integrating economics into the rationale for multisectoral action on obesity
}

\author{
Vivian L. Ellis ${ }^{1}$ and Olga V. Milliken ${ }^{1}$
}

Suggested citation

Ellis VL, Milliken OV. Integrating economics into the rationale for multisectoral action on obesity. Rev Panam Salud Publica. 2018;42:e58. https://doi.org/10.26633/RPSP.2018.58

\begin{abstract}
Obesity is a compelling example of the challenges of championing and mobilizing a response that involves the whole of government and all of society. This paper discusses the need for economic rationales to strengthen the case for government intervention on obesity, with a view to better engaging the expertise and resources of nonhealth sectors. The paper also briefly reviews economic theory and evidence that could support an integrated multisectoral rationale for action, noting opportunities to expand the integration of economic evidence in the Americas.
\end{abstract}

Keywords Obesity; models, economic; health behavior; health economics; public health.

Taking action to address obesity, particularly childhood obesity, has high priority in the Americas for government investments and for efforts involving all of society. Member States of the Pan American Health Organization (PAHO) have adopted various multilateral frameworks to address obesity. The PAHO fiveyear Plan of Action for the Prevention of Obesity in Children and Adolescents (1) provides a framework for action for Member States. The World Health Organization (WHO) Global Action Plan for the Prevention and Control of Noncommunicable Diseases 2013-2020, the PAHO Strategy for the Prevention and Control of Noncommunicable Diseases, and the PAHO Plan of Action for the Prevention and Control of Noncommunicable Diseases target actions on unhealthy diets

\footnotetext{
Centre for Chronic Disease Prevention and Health Equity and WHO Collaborating Centre on Noncommunicable Disease Policy, Public Health Agency of Canada, Ottawa, Canada. Send correspondence to Vivian Ellis at vivian.ellis@canada.ca.
}

and physical inactivity, which are key modifiable risk factors for obesity $(2,3)$.

Nevertheless, making concerted action on obesity a reality remains a challenge for many Member States (4). Consensus within public health authorities and academics (5) is not generally enough to convince other sectors within governments and throughout societies to take comprehensive multisectoral action. For example, in 2016, while almost twothirds of PAHO Member States reported having multisectoral plans for NCDs, including obesity, only one-fifth reported policies in place to promote healthy eating by reducing the impact on children of marketing of foods, including nonalcoholic beverages and foods high in sugar (6). Considering the unanimity for scaling up action, the questions arise: What's missing? What could strengthen the case in the Americas?

While concerted political leadership can mobilize nonhealth actors $(7,8)$, public health experts recognize that engaging nonhealth sectors, within and without governments, typically requires a solid economic case for action. Otherwise, nonhealth actors may see themselves neither in the problem nor its solutions. Global and regional policy documents (2, 3) have stressed the importance of economic and development impacts in the rationale to scale up action on obesity. Conversely, lack of solid economic rationales can legitimize resistance to obesity action. Additionally, multilateral funders and central agencies within governments may require economic rationales to support budget decisions or regulations.

This paper highlights economic rationales for government intervention on obesity. The article briefly reviews economic theory and evidence that could support an integrated rationale for multisectoral action, highlighting evidence from the Americas. The authors' companion paper (9) in this special supplement discusses gaps in methods and evidence needed for a comprehensive investment case. 


\section{WHAT WILL ECONOMIC DECISIONMAKERS LOOK FOR IN THE CASE FOR OBESITY ACTION?}

With some exceptions (10), public health rationales for action often have no or limited economic insights, despite their emphasis on societal benefits. Or, economic rationales are advanced in a secondary analysis developed after the epidemiological one. For example, in Canada, there has been a recurring knowledge gap with respect to economic evidence and analysis in the study of public health, including on obesity (11). A recent report by the National Academies of Science, Engineering, and Medicine of the United States of America (12) found that while economic evidence has potential to show not just what works, but what works within budget constraints, in practice such evidence may not be effectively produced or applied. In Latin America and the Caribbean (LAC), there is sparse, but widely varying, evidence of the health care cost burden of obesity (13). Further, in LAC, evidence from economic evaluations is uncommon in health policy formation, and few nutrition and physical activity interventions have economic evaluations (9).

Additionally, across the Americas, what economic evidence there is draws most heavily on health sector data. Verifiable health care system costs can be compelling. However, evidence of causes, risks, costs, and benefits that is focused on the health sector can convey the message that obesity is fundamentally a health sector management problem. Health care expenditures alone do not demonstrate why others should engage their resources towards the solution. Nonhealth actors may take the position that obesity needs to be addressed by better priority setting and more efficient use of resources within the health sector.

The economic burden of obesity is alarmingly large (9). Nevertheless, a descriptive measure of that burden would not in itself provide a sufficient justification for what many economic sectors would see as intrusion into markets and individual choices. Nor would that measure guide policy responses or explain why nonhealth sectors need to engage in solutions. Experts from sectors where economics provides the primary underpinning for policy analysis will ask why government intervention is needed and why their sector needs to be engaged. Their starting point is that societal well-being is optimized as long as markets are working perfectly. Thus, they will seek an explanation why, in a particular case, markets do not work perfectly. That is, they will seek a causal explanation, grounded in economic theory, why individuals and producers are not making healthy choices on their own. Consequently, these economic specialists will expect economic analyses and evidence of causes, risks, and the costs and benefits of intervention that are more comprehensive than those familiar to public health specialists. They will also pose the question of how and by how much their sectors' and overall societal well-being will be impacted by intervention.

While traditional economic theory takes perfect markets as the starting point, it acknowledges that markets may fail to support optimal decision-making. When this happens, intervention may be justified to correct inefficiencies or to mitigate them. That said, the cost of inefficiencies needs to be weighed against the cost of correcting them and the distributional consequences of a corrective action (14). The scope of market failures is broad, and their impact is wide-ranging. Also, in practice, market failures, and interventions to mitigate them, may be sensitive to local or country contexts. Welfare economics is an established branch of economics that looks at the

FIGURE 1. Cycle for the integration of economic theory into multisectoral public health action on obesity

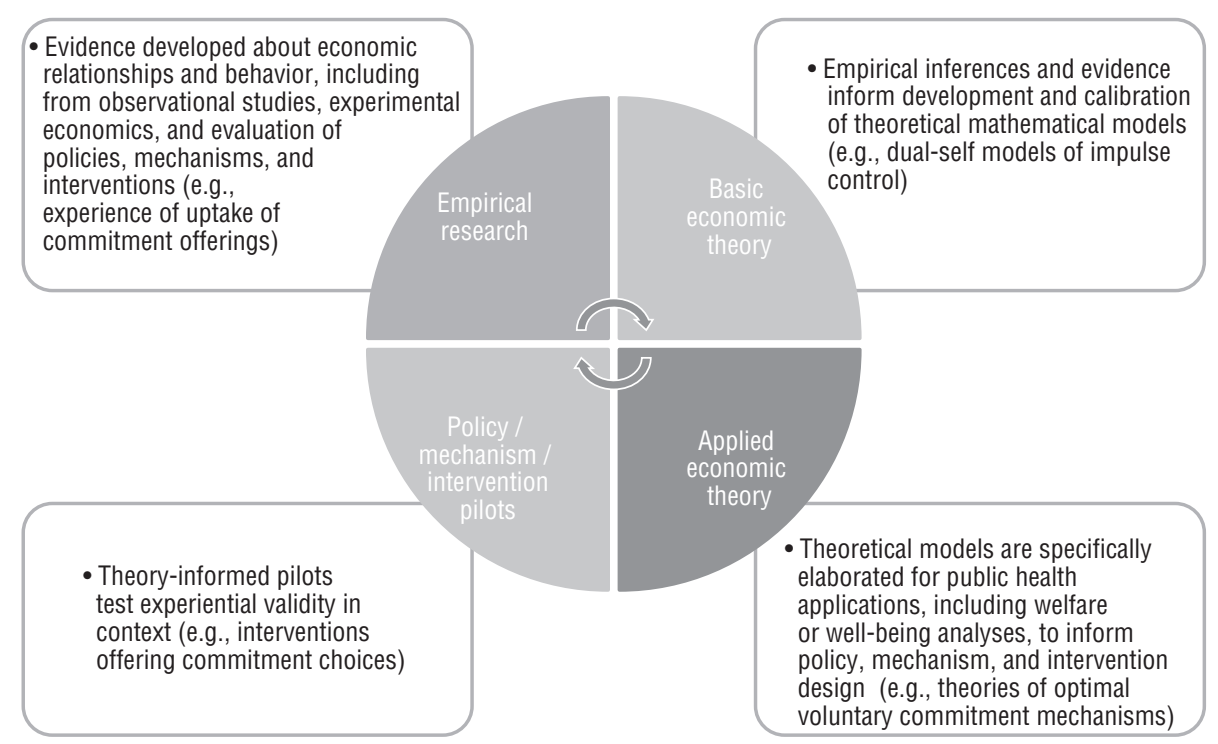

Source: Proposed and developed by the authors.

impact of policies on well-being at the level of individuals, markets, and society as a whole and that considers distributional effects. Our companion paper (9) looks at how welfare economics, particularly cost-benefit methodologies, can be used to assess an investment case for intervention.

Going beyond traditional market imperfections, economists increasingly recognize that human behavior is not consistent with the ideal of rationality used in traditional economic models (15). Behavioral economics provides an umbrella of approaches that seek to extend the standard economic framework and account for evidence on human behavior, by borrowing from psychology and sociology (16). Health behavior questions have been cited as inspirations for theoretical research in behavioral economics from the beginning. In practice, however, economists from nonhealth sectors are ahead in applying behavioral economics theory for public policy (16). Nonetheless, among health policymakers and practitioners, there is high interest in low- and middle-income countries, where a recent survey found an appetite to use insights from behavioral economics in the design and implementation of health policies (17). Figure 1 offers a visualization of a cycle in which innovations in economic theory are applied to obesity-related questions to inform interventions, which in turn calibrate and refine theory. 


\section{ECONOMIC RATIONALES FOR INTERVENTION TO PREVENT OBESITY}

Enabling individuals by "making healthy choices the easy choices" is a touchstone of public health policy formation, anchored in the 1986 Ottawa Charter for Health Promotion. Similarly, policy insights from economics about obesogenic behaviors and environments often focus on individuals, particularly choices involving risky health behaviors (18). Understanding individuals' economic choice behavior can also provide a framework to examine decisions by private and nonprofit firms and government entities, as well as to assess how changing market contexts impact choices.

\section{Individuals}

When making choices in the standard economic model as applied to health, individuals make tradeoffs that can have different health impacts. Individuals allocate time between income-earning work and "leisure." They then allocate income toward consuming healthy versus unhealthy products, as well as "leisure" time toward healthy activities (e.g., exercise, food preparation, nurturing, volunteering) versus unhealthy pastimes (e.g., screen time). Further, looking over the long term, individuals make tradeoffs between consuming now versus investing in their uncertain future health, which adds complexity. Under this standard economic model of choice, rational, forward-looking people choose to consume unhealthy products even though they know the risks to their future health. Government intervention would decrease societal well-being. However, economists have recognized that many people struggle unsuccessfully to adopt positive health behaviors (19). Economics' mathematical models of market failure and human behavior can explain why individuals struggle, and offer insights into policy responses.

If individuals place an incorrect or incomplete value on their consumption of a product or activity, they will either overconsume or underconsume. This market failure potentially leads to not only less benefit for themselves but also to a loss of overall societal welfare (well-being), referred to as a deadweight loss (DWL). Figure $2 \mathrm{a}$ and Figure $2 \mathrm{~b}$ are standard neoclassical representations that show the effect of underconsumption and of overconsumption as compared to consumption that maximizes societal wellbeing. When consumers undervalue a product or activity, they consume less than the societal optimum; when they overvalue a product or activity, they consume more than the societal optimum.

Imperfect information. How can individuals misvalue benefits and costs? Incomplete information is one classic explanation. When consumers do not know all about the costs, benefits, and risks of a behavior, they will overconsume unhealthy products and underconsume healthy ones (18). Policy prescriptions involving information dissemination are appealing to economists since addressing information gaps can raise societal well-being, with modest impact on other economic actors. However, information campaigns, such as mass media advertising, have been generally assessed within broader multi-intervention nutrition and activity strategies, so their impact is difficult to isolate (20). Moreover, they are most effective for one-time health behavior decisions rather than repetitive obesity-related choices about food, beverages, and physical activity (20).

Externalities. When individuals do not experience the full cost, benefit, or risk of their choice, others in society pay the costs, accrue the benefits, or bear the risk. The standard economic model describes this market failure as an externality. In standard health economics models, externalities can happen when individuals overvalue unhealthy choices or undervalue healthy ones because their future health maintenance costs are shared by insurers or the public system.

Again, Figure 2a and Figure $2 \mathrm{~b}$ show that individuals' valuation of their net benefit of consumption is either too high or too low compared to the societal valuation. With an externality, some of the costs and benefits go to another party, but there is still a loss of overall societal well-being (deadweight loss). The differential between societal and individual valuation can be magnified when individuals live in the present, discounting future impacts more than the insurer or government. Evidence on how much individuals need to be paid to risklessly postpone consumption varies across countries, possibly for economic or cultural reasons. Wang et al.'s recent comparison of 53 countries found that subjects from Latin America had the second-lowest willingness to wait to consume after those from Latin Europe and Africa (21). (The rate that individuals need to be paid to wait to consume is the riskless discount rate.)

As a policy response to an externality, sales and excise taxation on unhealthy products, or price subsidies on healthy ones, can close the gap in individuals'

\section{FIGURE 2. Loss of societal welfare (well-being) due to externalities in individuals' consumption choices ${ }^{a}$}

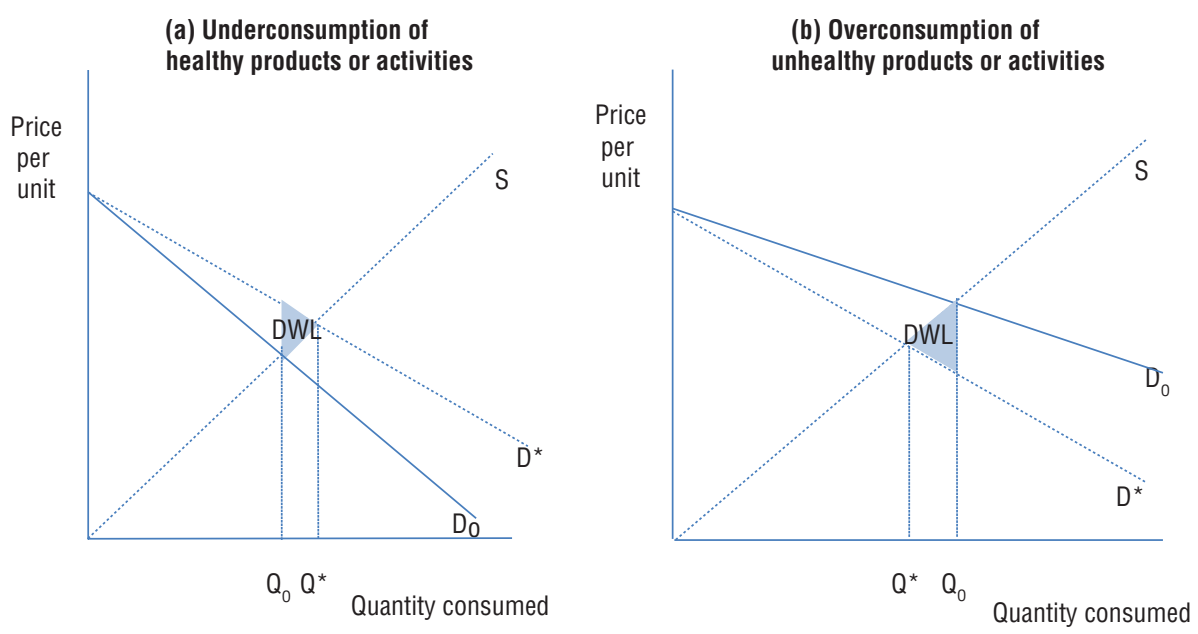

Source: Prepared by authors following standard neoclassical theory.

a Individuals' equilibrium consumption is not societally optimal when private valuations of products or activities do not match societal ones: (a) underconsumption of healthy products and activities; (b) overconsumption of unhealthy products and activities, with societal deadweight loss (DWL) in welfare. Correctly valued societal demand curve $\left(D^{*}\right)$ with optimal equilibrium quantity consumed $\left(Q^{*}\right)$; individuals' own privately valued demand curve $\left(D_{0}\right)$ and suboptimal quantity consumed $\left(Q_{0}\right)$; supply curve $(S)$. In $(a), Q_{0}<Q^{*} ;$ in $(b), Q_{O}>Q^{*}$. 
valuations. How much sales and excise taxes will move consumption, who will bear the incidence of the tax, and how much tax revenue will be raised will largely depend on how elastic, or sensitive, individuals' consumption choices are to price (that is, the price elasticity of demand). For example, if demand is very inelastic, consumers will typically bear much of the tax, but their behavior will not change much. Consumers' income will also impact their sensitivity to price changes, with lower-income groups being more sensitive. (The greater impact on low-income groups raises distributional questions. However, when consumption of unhealthy products falls in response to taxes, these groups obtain the greatest health benefit.)

Societal benefit will also depend on cross-elasticities that explain shifts in consumption of related products. ${ }^{2}$ Elasticities of demand can vary widely by country and subregion, leading to large variances in the effectiveness and distributional consequences of taxes.

In health economics, tobacco and alcohol have had priority in country-level research on elasticities of demand. There is sparse price elasticity evidence in the Americas for nonalcoholic beverages and food $(22,23)$, except for the United States (24), especially regarding cross-elasticities between key healthy and unhealthy substitutes. A recent multicountry report contributes own price and income elasticities for Latin America as a region (25). However, Mexico's soda tax experience shows that prospective studies limited to own price elasticities may underestimate a tax's impact, especially when it is rolled out in the context of a comprehensive set of interventions that promote healthy substitutes. A pretax study found inelastic demand (22), but posttax evaluations found large reductions in demand (26).

Nonstandard models: changing preferences, constrained rationality, and constrained self-control. The axioms of rational behavior underpinning economics' standard model are strong, especially to value risky future outcomes. Additionally, assumptions about unchanging individual preferences are

\footnotetext{
When the price of a taxed product increases, consumption of substitutes increases, while consumption of complements (e.g., bread used with sandwich fillings) decreases. Conversely, when a product is subsidized to lower its price, consumption of its substitutes will decrease, and consumption of its complements will increase.
}

embedded. So, while the individuals are modeled as thinking rationally in the "here and now" about a lifetime of choices, it is assumed that likes and dislikes for products or activities will not change, nor will their attitudes about risk, nor their impatience for consuming today versus tomorrow. That is, standard economic theory does not explain how individuals' preferences are formed or how they might be influenced to change. Even taking constant preferences as given, questions arise about whether rational choice represents the way people think (15). While workarounds for traditional assumptions and alternate theories are possible, the key test of validity is how well they match evidence on human behavior $(27,28)$ (Figure 1).

How consumption preferences change in response to previous consumption can account for many observed patterns of habituation and addiction. With habituation, changes in behavior may have only a small influence today, but a much larger result in the future, should the change in behavior be sustained. Rational addiction models assume that, for people who have consumed a habit-forming product or activity, the level of enjoyment from consumption today is reinforced by past consumption (19). (While the label "rational addiction" can be off-putting when viewed from a mental health context, the term "rational" relates to the standard economic model.) Rational addiction models explain dynamics in addictive behavior aligned with clinical findings, such as tolerance, withdrawal, and "quitting cold turkey." These models also predict that not everyone will become addicted. For policy prescriptions, they suggest that sales and excise taxes will be effective in discouraging starting and encouraging quitting, but also that those taxes need to be high in value and persistent (19). Rational addiction could explain evidence of the effectiveness of high tobacco and alcohol taxes (29).

Rational addiction models can, moreover, describe not only habituation to unhealthy substances, but also to healthy products and behaviors (e.g., physical activity) (19). In the case of food preference formation, such as for skim milk (30) or strong-tasting food, these models' inferences about human behavior appear consistent with psychological evidence (31). For nonalcoholic beverages, the evidence for habituation appears stronger for milk than for sugar-sweetened beverages (30). The emerging evidence of addiction among persons who excessively use computer games (32) or social media (33) suggests opportunities to extend these models to sedentary behaviors.

Changes over time in individuals' impatience or risk aversion also modify discount rates and how sensitive consumption today is to uncertain future outcomes (e.g., changes in future wealth or health status). This contradicts the standard model. Evidence about how much individuals need to be compensated for waiting varies across the life course, and with education, income, or wealth. Regarding risk, evidence shows individuals are risk averse in the short horizon, but more risk tolerant in the long run (27). Working out whether changes in impatience versus changes in risk aversion are at play is empirically challenging, but important because they have different policy implications (34). Evidence to date on discount rates in the health domain has focused on tobacco use $(35,36)$, but obesity-related evidence is emerging (37).

Hyperbolic discounting models can explain certain behaviors of consumers, with discount rates that differ when looking at the short term versus long term (time-inconsistent), particularly individuals' voluntary choices to commit to or lock in future consumption (19) (e.g., buying an annual gym membership). These models demonstrate that, counter to the assumptions of the standard model, it is not always better to have a larger set of consumption choices. These models provide rationales for governments to intervene to create commitment mechanisms that the private sector may not provide on its own (e.g., protecting from borrowing against retirement savings (38)), or to limit the available choices (e.g., with bans, restrictions) (38). Quasi-hyperbolic discounting models are a particular form (37) that additionally show how modest disincentives (e.g., taxes) or nudges (e.g., reward incentives) in the near term may shift behavior (38).

Dual-self models of impulse control are another way to model changing impatience. They explain individuals' impulse control challenges, including obesity-related behaviors (27). Taking from psychology and neuroscience insights about multiple selves, dual-self models show how a long-run, rational 
deliberative self is challenged to control the behavior of a more impulsive shortrun self in each time period. Because short-run self-control is costly, and gets more costly the greater the cognitive load, the individual will make impulsive, impatient choices that the deliberative self would not $(19,27)$. Commitment mechanisms can be beneficial in assisting the long-run self to constrain impulsive day-to-day choices (19). Dual-self models can also explain why the contexts in which products are offered matters: the greater the cognitive load, the more likely the individual will make an impulsive choice. This explains why contextual "nudges" to move consumer choices in supermarkets, or simplified front-ofpackage labeling, could work, and why government intervention into marketing contexts may be warranted. Early evidence shows consistency between obesogenic behavior and dual-self models (39-41). Evidence of specific cognitive constraints and limits, especially on intake and processing of complex information, are motivating innovative nudge interventions $(42,43)$.

Children challenge the standard rational economic model. Psychological evidence finds that children's food preference formation is influenced by exposure, associations with a positive event, and indications of liking by a significant other (peer, older child, teacher, parent) (31). Attempts to emphasize the beneficial consequences or to use rewards to influence food choices backfire (31). Influences outside the family are important in preference formation: parent-child correlations in liking for foods are very low, from as early as 4 years of age, when compared to correlations in values and attitudes (31). As such, the social and nutritional context plays an important role, and parents cannot be assumed to be making consumption decisions on their children's behalf.

Evidence from Chilean elementary students shows increased cognitive ability may reduce bias in children's choices, implying education policies that improve problem-solving ability may be protective (44). However, these are not likely to address obesogenic preferences established earlier.

Cawley (45) argues that "because children are not what economists call 'rational consumers'-they cannot evaluate information critically and weigh the future consequences of their actions-the government may step in to help them make better choices about obesogenic products." Neuroscience and neuropsychology evidence on executive functions affirms that "rationality" is undergoing development until early adulthood (46). That evidence may justify government interventions in the marketing and availability of obesogenic products to children and adolescents, similar to the ones for tobacco and alcohol.

\section{Private sector and civil society}

Individuals are not the only economic actors who may make societally suboptimal decisions. Firms, whether in the private or nonprofit sector, will make choices to maximize their own well-being. Engaging the private sector and civil society in obesity solutions can be better anchored by evidence about how they contribute to the problem or benefit from solutions.

Externalities arise when firms share the costs and benefits of investing in a healthy workforce with their employees. They may not consider the obesogenic impact of workplaces, especially if they do not view their relationships as long term or if costs today of health promotion are high. Evidence shows that economic upswings are periods of high NCD mortality in developed economic regions (e.g., northern Mexico (47)), sug- gesting a role for government intervention in the workplace.

Externalities can also arise when producers of unhealthy products use marketing and product design to take advantage of individuals' constraints in making healthy choices, whether in information (48) or impulse control. Industrial organization is a field of economics that looks at the structure of firms and markets, including pricing and product design. Modern agrifood markets do not reflect traditional assumptions of perfect information, homogenous goods, and small firms (49). Producers use information (e.g., labeling, advertising), pricing, product design and size (49), and store location or layout $(40,41)$ to influence choices. These factors could promote obesity. Also, dominant producers may be incented to influence public perceptions through media or funded research ("deep capture") (50). Figure $3 a$ and Figure $3 \mathrm{~b}$ show how firms will underproduce healthy products and overproduce unhealthy ones when they do not experience the full societal benefits or costs of their production. There is evidence showing that supermarket and fast food location impacts obesity (51), but limited research on other producer/ seller decisions (52). Further, self-regulation by producer-controlled marketing associations has become the norm (49). Government intervention to bring firms'

\section{FIGURE 3. Loss of societal welfare (well-being) due to externalities in firms' production} choices $^{a}$

(a) Underproduction of healthy products

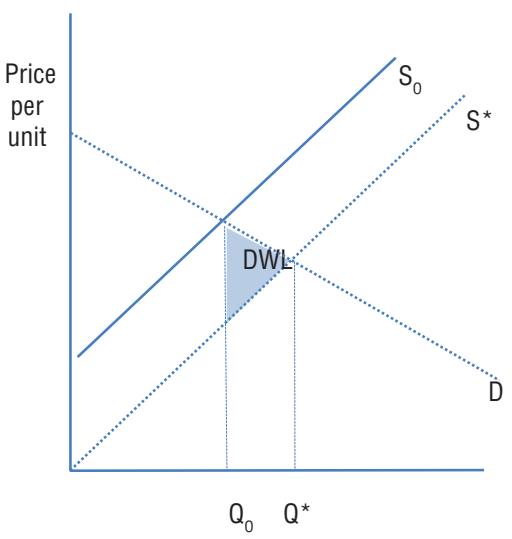

(b) Overproduction of unhealthy products

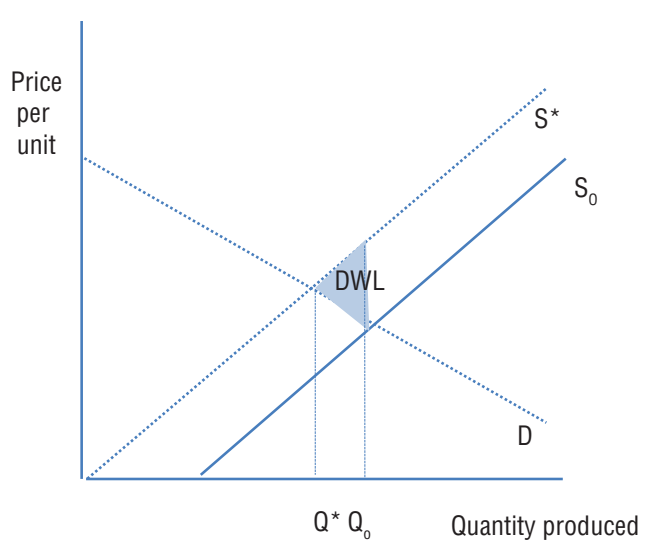

Source: Prepared by authors following standard neoclassical theory.

a Firms' equilibrium production is not socially optimal when firms' private valuations do not match societal ones: (a) underproduction of healthy products; (b) overproduction of unhealthy products, with societal deadweight loss (DWL) in welfare; societally valued supply curve $\left(S^{\star}\right)$ and optimal equilibrium quantity $Q^{*}$; firms' own value supply curve $\left(S_{0}\right)$ and suboptimal quantity produced $\left(Q_{0}\right)$; demand curve (D). In (a), $Q_{0}<Q^{*} ;$ in (b), $Q_{O}>Q^{*}$. 
valuation of costs and benefits in line with societal ones may be justified to increase overall well-being.

\section{Governments}

Government measures for nonhealth sectors may unintentionally promote obesogenic behavior. One documented example in the Americas is that domestic agricultural subsidies distort relative prices, lowering the cost of calorie-dense foods and making healthy foods less affordable $(14,53)$. However, simple reversal of such measures might not return markets and consumption patterns to their initial conditions (53). In the Caribbean, trade liberalization has led to decreased local production, increased food imports, and changes in food choices (54). Measures to mitigate adverse obesity-related impacts of nonhealth sector policies may be warranted.

\section{Changing market contexts}

Looking at economic rationales one by one can beg the question of why obesity trends increased so sharply (55). An answer lies in the profound changes in market and social contexts in recent decades, to which the economic rationales described above are sensitive. Cawley's narrative review of obesity's causes, consequences, and solutions explores these changes (56). In Latin America, globalization, urbanization, and rising incomes are associated with changing diet and physical activity habits. For example, there are increasing intakes of total fat, animal products, and sugar, and rapid declines in the intake of cereals, fruit, and some vegetables (57). Globally, several multicountry reviews have examined pathways for impact. Regarding economic growth, a review of 175 countries found that the benefits of rising gross domestic product (GDP) on body mass index plateau at GDP per capita > US\$ 3 000, and that lower income inequalities and more regulated markets appear protective against obesity in countries with GDP > US\$ 30000 per capita (58). Liberalization and globalization of agricultural markets has impacted incentives to producers; altered nutritional quality and content; and increased the variety and quantity of food available (59). On technology-induced change, an analysis of 244 Demographic and Health
Surveys found that overweight is associated with urbanization and car and television ownership generally; with greater calorie intake in middle-income countries; and with shifts away from agricultural employment in low- and middle-income countries (60). One study found globalization's social dimensions, specifically "information flows" and "social proximity," account for more of rising obesity than do its economic dimensions (i.e., trade and foreign investment) (61). To the extent that national and global development and macroeconomic and trade policies and frameworks have contributed to these changing contexts, consideration of measures targeted at mitigating their adverse obesity-related impacts may be justified.

\section{DISCUSSION}

There is growing recognition that "shortcomings in economic evidence weaken society's ability to invest wisely and also reduce future demand for this and other types of evidence" (12). Dialogues to enhance the uptake of economics in public health have taken place in Canada (11), the United States (12), and through workshops convened by PAHO. By using economic evidence, policymakers and practitioners can both strengthen the case for action on obesity and encourage economists to enrich the evidence base and apply theory to inform effective policy innovation, as illustrated by Figure 1. A new Economics of Obesity Special Interest Group established by the International Health Economics Association demonstrates academic economists' engagement in policy-relevant applications (62).

This paper is not exhaustive in its exploration of economic rationales, but rather intends to provide an entry point for policymakers and to identify opportunities for further research. Table 1 relates relevant economic theories to potential policy interventions.

We found potentially important underexplored areas of economic research. Compared to tobacco (e.g., (63)), obesity has a scant peer-reviewed literature in industrial organization, pricing, and product design. (Searching the EconLit database using the keywords "industrial organization" or "product design" and "obesity" yielded few results. "Pricing and obesity" results mainly concerned taxation or "food deserts.") Additionally, sociology and psychology offer complementary perspectives on the evolving socioeconomic context for obesity. While behavioral economics is incorporating insights from these disciplines, we found limited progress in applying relevant economic models of learning or mechanism/contract design to health-related interventions or policy questions. Also, recent evidence about the social influences on individuals' obesity-related consumption preferences during adulthood (64) suggests further refinements for economic models of choice.

Interested readers can find more expansive reviews of the existing literature in work by Cawley and Ruhm (18), Kenkel and Sindelar (19), and Cawley (56). Kessler looks at obesity-relevant applications in four major topic areas: reward incentives, information and salience, context and framing, and social forces (42). Monroy examines applying behavioral economics to eating behavior within a Latin American context (38). Unnevehr (65) reviews food and health from an agricultural economics' perspective, including the policy implications of price elasticities.

\section{Conclusions}

In sum, championing and mobilizing action across all sectors of society is better supported when its public health rationale includes causes and evidence that speak to diverse economic actors. Economics research is policy-relevant and compelling to nonhealth actors. Integration of a broader scope of economic theory and evidence into the case for obesity action is needed.

This article provides a brief narrative review of key economic rationales for action on obesity and considers Americas-specific evidence. It seeks to motivate public health practitioners to incorporate a broader scope of economics into their analysis, and researchers to enrich the evidence base. Important gaps in economic analysis of obesity include industrial organization as well as region-specific assessments of the key market failures and constraints on rationality. There is significant and extensive evidence of changes in the market context and demographics associated with changes in dietary and physical activity patterns, including for 
TABLE 1. Relating theoretical economic models to evidence for Latin America and the Caribbean and to potential interventions

\begin{tabular}{|c|c|c|c|}
\hline $\begin{array}{l}\text { Economic model type, } \\
\text { (reference(s)) }\end{array}$ & $\begin{array}{l}\text { Difference from standard } \\
\text { economic model of perfect } \\
\text { markets, (reference(s)) }\end{array}$ & $\begin{array}{l}\text { Evidence for Latin America } \\
\text { and the Caribbean, with first } \\
\text { author, year, (reference) }\end{array}$ & Theoretical options for intervention, (reference(s)) \\
\hline $\begin{array}{l}\text { Information market failure } \\
\text { model (18) }\end{array}$ & Incomplete information & $N A^{a}$ & $\begin{array}{l}\text { Public information }(18,19) \text { (e.g., mass media advertising); disclosure } \\
\text { requirements (18) (e.g., labeling (19)); advertising bans (18) }\end{array}$ \\
\hline Market failure models (18) & External costs and benefits & Colchero, 2017 (26) & $\begin{array}{l}\text { Sales and excise taxes (18); eliminating/avoiding subsidies of unhealthy } \\
\text { products }(18,53)\end{array}$ \\
\hline $\begin{array}{l}\text { Habituation and rational } \\
\text { addiction models }(18,19,29)\end{array}$ & $\begin{array}{l}\text { Individuals' preferences depend } \\
\text { on past consumption }\end{array}$ & NA & $\begin{array}{l}\text { High and persistent sales and excise taxes }(18,19) \text {; restricted availability } \\
\text { (bans, point-of-purchase restrictions) }(19)\end{array}$ \\
\hline $\begin{array}{l}\text { Hyberbolic discount rate } \\
\text { models }(19,37)\end{array}$ & $\begin{array}{l}\text { Risk and consumption } \\
\text { preferences change over time }\end{array}$ & Monroy, 2017 (38) & Commitment mechanisms (19); reducing product diversity, bans (19) \\
\hline $\begin{array}{l}\text { Quasi-hyperbolic discount } \\
\text { rate models ( } 37 \text { ) }\end{array}$ & $\begin{array}{l}\text { Risk and consumption } \\
\text { preferences change over time }\end{array}$ & Monroy, 2017 (38) & $\begin{array}{l}\text { Nudges (e.g., reward incentives, modest subsidies or taxes) (19); } \\
\text { commitment mechanisms(19); reducing diversity of available } \\
\text { products(19); bans (19) }\end{array}$ \\
\hline $\begin{array}{l}\text { Dual-self models of impulse } \\
\text { control }(19,27)\end{array}$ & $\begin{array}{l}\text { Risk preferences changing; } \\
\text { self-control and cognitive } \\
\text { processing costly }\end{array}$ & NA & $\begin{array}{l}\text { Commitment mechanisms }(19,27) \text {; (dis-)incentives and price interventions } \\
\text { (taxes, subsidies, reward incentives, small payments, restrictions on price } \\
\text { or volume promotions) (19); cognitive load interventions (reminders, } \\
\text { labeling, point-of-sale interventions) (40, 41); reducing availability (e.g., } \\
\text { locations with limitations on unhealthy foods) (19) }\end{array}$ \\
\hline Bounded rationality & $\begin{array}{l}\text { Rationality not fully developed } \\
\text { (e.g., children) (45) }\end{array}$ & Benjamin, 2013 (44) & $\begin{array}{l}\text { Education promoting development of executive function and problem- } \\
\text { solving ability }(18,44) \text {; restrictions on marketing and availability }(18,45)\end{array}$ \\
\hline $\begin{array}{l}\text { Information } \\
\text { "deep capture" (50) }\end{array}$ & $\begin{array}{l}\text { Asymmetric information and } \\
\text { dominant producers/sellers }\end{array}$ & NA & $\begin{array}{l}\text { Public information (18); research dissemination (18); regulation of health } \\
\text { messaging (19); disclosure requirements (19) }\end{array}$ \\
\hline $\begin{array}{l}\text { Industrial organization } \\
\text { location models ( } 51)\end{array}$ & $\begin{array}{l}\text { Geographic concentration of } \\
\text { sellers is not constant }\end{array}$ & NA & Incentives for supermarket placement (51) \\
\hline
\end{tabular}

Source: Authors' review.

a NA = not applicable; obesity-related evidence for Latin America and the Caribbean was not found in the course of the authors' searches.

the Americas, particularly due to globalization, urbanization, and rising income levels. These changing environments can help explain why economic rationales, which were not as crucial in the past, justify intervention now.

Acknowledgments. This paper has been facilitated by a discussion at a thematic working group virtual meeting and by comments from participants of the in-person meeting on Advancing Economics for Prevention and Control of Noncommunicable Diseases in the Americas organized by PAHO in 2016. The authors thank John Cawley, Brian Ferguson, colleague Juan Andrés León, guest technical editors, and anonymous referees for their valuable comments.
Funding. The authors are employees of the Government of Canada.

\section{Conflicts of interest. None declared.}

Disclaimer. The views expressed in this manuscript do not necessarily reflect those of the Government of Canada, and may not necessarily reflect the opinion or policy of the RPSP/PAJPH or PAHO.

\section{REFERENCES}

1. Pan American Health Organization. Plan of Action for the Prevention of Obesity in Children and Adolescents. Washington, D.C.: PAHO; 2015. Available at: http:// www.paho.org/hq/index.php?option= com_content \&view=article \& $\mathrm{id}=11373 \% 3 \mathrm{~A}$ plan-of-action-preventionobesity-children-adolescents\&catid $=8358$ $\% 3$ Aobesity\&Itemid $=4256 \&$ lang $=$ en Accessed 15 January 2018.

2. World Health Organization. Global Action Plan for the Prevention and Control of Noncommunicable Diseases 2013-2020. In: World Health Organization. Follow-up to the political declaration of the High-level Meeting of the General Assembly on the Prevention and Control of Noncommunicable Diseases. (WHA66.10). Geneva: WHO; 2013:7-55. Available at: http: / / apps.who.int/gb/ebwha / pdf_files /WHA66/A66_R10-en.pdf?ua=1 Accessed 19 September 2017.

3. Pan American Health Organization. Plan of Action for the Prevention and Control of Noncommunicable Diseases in the Americas 2013-2019. Washington, D.C.: PAHO; 2014. Available at: http://www. paho.org $/$ hq/index.php?option $=\mathrm{com}_{-}$ content\&view =article\&id $=8621$ $\% 3$ A 2013 -strategy-plan-actionprevention-control-noncommunicablediseases \& catid $=3697 \% 3$ Ageneral \& Itemid=39974\&lang=en Accessed 10 October 2017.

4. Pan American Health Organization. Plan of Action for the Prevention and Control of Noncommunicable Diseases: midterm review. Washington, D.C.: PAHO; 2016. Available at: http://iris.paho.org/xmlui/ bitstream/handle/123456789/33737/
CE158-INF-13-C-e.pdf?sequence=7\&isAllowed=y Accessed 15 January 2018.

5. Swinburn B, Dietz W, Kleinert S. A Lancet Commission on obesity. Lancet. 2015 Oct 31;386(10005):1716-7.

6. World Health Organization. Noncommunicable Diseases Progress Monitor 2017. Geneva: WHO; 2017. Available at: http: / / apps.who.int/iris/bitstre am/10665/258940/1/9789241513029-eng. pdf?ua $=1$ Accessed 10 October 2017.

7. Geneau R, Fraser G, Legowski B. Mobilizing intersectoral action to promote health: the case of ActNowBC in British Columbia, Canada. Ottawa: Public Health Agency of Canada; 2010. Available at: http://publications.gc.ca/ collections / collection_2010/aspcphac/HP5-85-2009-eng.pdf Accessed 16 October 2017. 
8. Charvel S, Cobo F, Hernández-Ávila M. A process to establish nutritional guidelines to address obesity: lessons from Mexico. J Public Health Policy. 2015;36(4):426-39.

9. Milliken O, Ellis V. Development of an investment case for obesity prevention and control: perspectives on methodological advancement and evidence. Rev Panam Salud Publica 2018;42:e62. https://doi. org/10.26633/RPSP.2018.62.

10. Yach D, Stuckler D, Brownell K. Epidemiologic and economic consequences of the global epidemics of obesity and diabetes. Nat Med. 2006;12(1):62-6. Erratum in Nat Med. 2006 Mar;12(3):367.

11. Canadian Institutes of Health Research, the Institute of Population and Public Health, the National Collaborating Centres for Public Health, the Canadian Population Health Initiative of the Canadian Institute for Health Information, and the Public Health Agency of Canada. Advancing population and public health economics: workshop proceedings. Ottawa: Government of Canada; 2013. Available at: http://publications.gc.ca/ collections/collection_2017/aspc-phac/ HP5-126-2013-eng.pdf Accessed 15 January 2018.

12. National Academies of Sciences, Engineering, and Medicine. Advancing the power of economic evidence to inform investments in children, youth, and families. Washington, D.C.: National Academies Press; 2016. Available at: http:/ / nationalacademies.org/hmd/ reports / 2016/advancing-the-power-of-economic-evidence-to-inform-investments-in-children-youth-and-families.aspx Accessed 16 October 2017.

13. Cuadrado C. Projecting costs of obesity in Chile (and Latin-America): data and method issues. Presentation at: Advancing Economics for the Prevention and Control of NCDs in the Americas; 2016 Aug 31Sept 1; Washington, D.C.

14. Sassi F, Hurst J. The prevention of lifestyle-related chronic diseases: an economic framework. Available at: https://search. oecd.org/health/health-systems/40324263. pdf Accessed 19 September 2017.

15. McFadden D, Machina MJ, Baron J. Rationality for economists? In: Fischhoff B, Manski CF, eds. Elicitation of preferences. Dordrecht: Springer; 1999:73-110.

16. Diamond P, Vartiainen H. Introduction. In: Diamond $\mathrm{P}$, Vartiainen $\mathrm{H}$, eds. Behavioral economics and its applications. Princeton: Princeton University Press; 2012:1-6.

17. Trujillo AJ, Glassman A, Fleisher LK, Nair D, Duran D. Applying behavioural economics to health systems of low- and middle-income countries: what are policymakers' and practitioners' views? Health Policy Plan. 2014;30(6):747-58.

18. Cawley J, Ruhm CJ. The economics of risky health behaviors. In: McGuire TG, Pauly MV, Barros PP, eds. Handbook of health economics. Vol. 2. Amsterdam: Elsevier; 2012:95-182.

19. Kenkel DS, Sindelar J. Economics of health behaviors and addictions: contemporary issues and policy implications. In: Glied S,
Smith PC, eds. The Oxford handbook of health economics. Oxford: Oxford University Press; 2011:206-31.

20. Wakefield M, Loken B, Hornik R. Use of mass media campaigns to change health behaviour. Lancet. 2010;376(9748): 1261-71.

21. Wang M, Rieger MO, Hens T. How time preferences differ: evidence from 53 countries. J Econ Psychol. 2016;52:115-35.

22. Escobar MAC, Veerman JL, Tollman SM, Bertram MY, Hofman KJ. Evidence that a tax on sugar sweetened beverages reduces the obesity rate: a meta-analysis. BMC Public Health. 2013;13(1):1072.

23. Paraje G. The effect of price and socioeconomic level on the consumption of sugar-sweetened beverages (SSB): the case of Ecuador. PloS One. 2016;113. Available at: https://doi.org/10.1371/journal pone.0152260 Accessed 10 October 2017.

24. Andreyeva T, Long MW, Brownell KD. The impact of food prices on consumption: a systematic review of research on the price elasticity of demand for food. Am J Public Health. 2010;100(2):216-22.

25. Muhammad A, D'Souza A, Meade B, Micha R, Mozaffarian D. The influence of income and prices on global dietary patterns by country, age, and gender. (ERR225). Washington, D.C.: U.S. Department of Agriculture, Economic Research Service. Available at: https://www.ers. usda.gov/webdocs/publications/82545/ err-225.pdf?v=42796 Accessed 2 January 2018.

26. Colchero MA, Rivera-Dommarco J, Popkin $\mathrm{BM}, \mathrm{Ng}$ SW. In Mexico, evidence of sustained consumer response two years after implementing a sugar-sweetened beverage tax. Health Aff (Millwood). 2017 Mar 1;36(3):564-71.

27. Fudenberg D, Levine DK, Maniadis Z. An approximate dual-self model and paradoxes of choice under risk. J Econ Psychol. 2014;41:55-67.

28. Nakamura R, Suhrcke M, Zizzo DJ. A triple test for behavioral economics models and public health policy. Theory Decis. 2017;83(4):513-33.

29. Chaloupka FJ, Warner KE. The economics of smoking. In: Culyer A, Newhouse J, eds. Handbook of health economics. Vol. 1. Amsterdam: Elsevier; 2000:1539-1627.

30. Zhen C, Wohlgenant MK, Karns S, Kaufman P. Habit formation and demand for sugar-sweetened beverages. Am J Agric Econ. 2011;93(1):175-93.

31. Rozin P. Food preferences, psychology and physiology of. In: Wright JC, ed. International encyclopedia of the social \& behavioral sciences. 2nd ed. Oxford: Elsevier; 2015:296-9.

32. Grüsser S, Thalemann R, Griffiths $M$. Excessive computer game playing: evidence for addiction and aggression? Cyberpsychol Behav. 2006;10(2):290-2.

33. Kwon HE, So H, Han SP, Oh W. Excessive dependence on mobile social apps: a rational addiction perspective. Inf Syst Res. 2016;27(4):919-39.

34. Khalil EL. Introduction: a taste for every season. In: Khalil EL, ed. The new behavioral economics. Volume 1. A taste for fairness. Cheltenham: Edward Elgar; 2009:ix-xxii

35. Barlow P, McKee M, Reeves A, Galea G, Stuckler D. Time-discounting and tobacco smoking: a systematic review and network analysis. Int J Epidemiol. 2016;46(3):860-9.

36. Khwaja A, Silverman D, Sloan F. Time preference, time discounting, and smoking decisions. J Health Econ. 2007;26(5): 927-49.

37. Courtemanche C, Heutel G, McAlvanah P. Impatience, incentives and obesity. Econ J. 2015;125(582):1-31.

38. Monroy C DA. Nudges y decisiones inconscientes: sesgo de statu quo y políticas públicas en Colombia. Desafíos. 2017;29(1):211-47. Available at: http:// www.scielo.org.co/pdf/desa/v29n1/ v29n1a08.pdf Accessed on 16 October 2017.

39. Ruhm CJ. Understanding overeating and obesity. J Health Econ. 2012;31(6):781-96.

40. Carroll KA, A Samek A, Zepeda L. Product bundling as a behavioral nudge: investigating consumer fruit and vegetable selection using dual-self theory. 2016 AAEA Annual Meeting Selected Papers; 2016 Jul 31-Aug 2. Milwaukee: Agricultural and Applied Economics Association; 2016. Available at: http://ageconsearch.umn. edu/record/236130 Accessed 2018 Jan 15.

41. Yim M. When shoppers don't have enough self-control resources: applying the strength model of self-control. J Consum Mark. 2017 Jun 12;34(4):328-37.

42. Kessler J, Zhang C. Behavioral economics and health. (Chapter 130). In: Detels R, Gulliford M, Karim Q, Tan C, eds. The Oxford textbook of global public health. $6^{\text {th }}$ ed. Oxford: Oxford University Press; 2015:1-38

43. Cutler D, Glaeser E. Why do Europeans smoke more than Americans? In: Wise D, ed. Developments in the economics of aging. Chicago: University of Chicago Press; 2009:255-82.

44. Benjamin DJ, Brown SA, Shapiro JM. Who is "behavioral"? Cognitive ability and anomalous preferences. J Eur Econ Assoc. 2013;11(6):1231-55.

45. Cawley J. Markets and childhood obesity policy. Future Child. 2006;16(1):69-88.

46. Diamond A. Executive functions. Annu Rev Psychol. 2013;64:135-68.

47. Gonzalez F, Quast T. Mortality and business cycles by level of development: evidence from Mexico. Soc Sci Med. 2010;71(12):2066-73.

48. Persson P. Attention manipulation and information overload. Available at: http:// www.nber.org/papers/w23823 Accessed 4 January 2018.

49. Saitone TL, Sexton RJ. Product differentiation and quality in food markets: industrial organization implications. Annu Rev Resour Econ. 2010. 2:17.1-17.28.

50. Smith T, Tasnádi A. The economics of information, deep capture, and the obesity debate. Am J Agric Econ. 2014;96(2): 533-41.

51. Powell LM, Han E, Chaloupka FJ. Economic contextual factors, food consumption, and 
obesity among U.S. adolescents. J Nutr. 2010 Jun;140(6):1175-80.

52. Dobson P. The lure of supermarket special offers: a healthy choice for shoppers. Available at: http://doc.ukdataservice. ac.uk/doc/7032/mrdoc/pdf/7032userguide.pdf Accessed 10 January 2018.

53. Nugent R. Food and agriculture policy: issues related to prevention of noncommunicable diseases. Food Nutr Bull. 2004;25(2):200-7.

54. Dorodnykh E. Trade liberalization and food import dependency. In: Economic and social impacts of food self-reliance in the Caribbean. Cambridge: Palgrave MacMillan; 2017:7-13.

55. Philipson T, Posner R. Is the obesity epidemic a public health problem? A decade of research on the economics of obesity. Available at: http://www.nber.org/ papers/w14010 Accessed 19 September 2017.

56. Cawley J. An economy of scales: a selective review of obesity's economic causes, consequences, and solutions. J Health Econ. 2015;43:244-68.

57. Bermudez OI, Tucker KL. Trends in dietary patterns of Latin American populations. Cad Saude Publica. 2003;19:S87-S99.

58. Egger G, Swinburn B, Islam FA. Economic growth and obesity: an interesting relationship with world-wide implications. Econ Hum Biol. 2012;10(2):147-53.

59. Hawkes C, Friel S, Lobstein T, Lang T. Linking agricultural policies with obesity and noncommunicable diseases: a new perspective for a globalising world. Food Policy. 2012;37(3):343-53.

60. Goryakin Y, Suhrcke M. Economic development, urbanization, technological change and overweight: What do we learn from 244 Demographic and Health Surveys? Econ Hum Biol. 2014;14:109-27.

61. Costa-Font J, Mas N. 'Globesity'? The effects of globalization on obesity and caloric intake. Food Policy. 2016;64:121-32.

62. International Health Economics Association. Special interest group: economics of obesity. iHEA Newsl. 2017 Oct:3. Available at: https:/ /c.ymcdn.com/ sites/www.healtheconomics.org/resource/resmgr/files/Newsletter/iHEA News_-_full_text_-_Oct_.pdf Accessed 15 January 2018.

63. Gilmore A. Understanding the vector in order to plan effective tobacco control policies: an analysis of contemporary tobacco industry materials. Tob Control. 2012 Mar;21(2):119-26.

64. Higgs S, Thomas J. Social influences on eating. Curr Opin Behav Sci. 2016;9:1-6.

65. Unnevehr LJ. Food and health: Can economics contribute to improved outcomes? Am J Agric Econ. 2012;95(2):220-7.

Manuscript received on 20 October 2017. Revised version accepted for publication on 22 January 2018.

RESUMEN La obesidad es un ejemplo contundente de los retos que implica el defender y movilizar una respuesta que abarque a todo el gobierno y toda la sociedad. En este artículo se aborda la necesidad de contar con fundamentos económicos para respaldar la pertinencia de la intervención gubernamental en materia de obesidad, a fin de incorporar

Integrar la economía en los fundamentos de la acción multisectorial en materia de obesidad

Palabras clave la pericia y los recursos de sectores ajenos al sector de la salud. En el artículo también se examina brevemente la teoría económica y la evidencia que podrían sustentar un fundamento multisectorial integrado para la acción, a la vez que se destacan las oportunidades para ampliar la integración de la evidencia económica en la Región de las Américas.

Obesidad; modelos económicos; conductas saludables; economía de la salud; salud pública.

A obesidade é um bom exemplo do desafio de defender e mobilizar uma resposta que envolva o governo e a sociedade como um todo. Este artigo aborda a necessidade de fundamentação econômica para fortalecer o argumento para a intervenção do governo na obesidade visando atrair mais conhecimento especializado e recursos dos setores externos à saúde. $\mathrm{O}$ artigo analisa resumidamente a teoria econômica e as evidências

Integrar aspectos econômicos à fundamentação para ação multissetorial em obesidade

Palavras-chave que poderiam embasar uma fundamentação multissetorial integrada para ação e destaca as oportunidades para ampliar a integração das evidências econômicas nas Américas.

Obesidade; modelos econômicos; comportamentos saudáveis; economia da saúde; saúde pública. 